\title{
Clostridium difficile sýkingar á Landspítala 1998-2008
}

\section{Rúnar Bragi Kvaran' læknanemi \\ Elsa Björk Valsdóttir ${ }^{1,2}$} skurðlæknir

\section{Helgi Kjartan Sigurðsson ${ }^{2}$} skurðlæknir

Magnús Gottfreðsson ${ }^{1,3}$ lyf- og smitsjúkdómalæknir

Lykilorð: Clostridium difficile, sýklalyf, ristilbólga, faraldsfræði, spítalasýkingar.

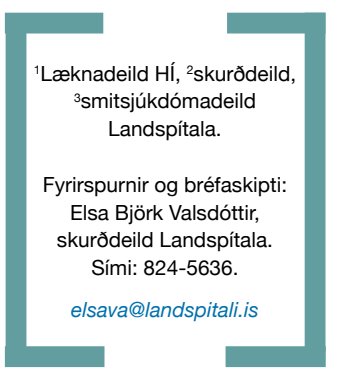

\section{Ágrip}

Tilgangur: Að kanna faraldsfræði og alvarleika ristilbólgu af völdum C. difficile á Landspítala og meta hvort meinvirkni sýkingarinnar hafi aukist á Íslandi líkt og víða á Vesturlöndum.

Efniviður og aðferðir: Sýkingar af völdum C. difficile á Landspítala árin 1998-2008 voru fundnar með pví að finna jákvæð eiturefnapróf 1 hægðasýnum úr gagnagrunni sýklafræðideildar. Úrtak klínískra upplýsinga um sjúklinga sem voru greindir í janúar og júní hvert ár á rannsóknartímabilinu var skoðað sérstaklega. Alls voru pað 237 sýkingar.

Niðurstöður: Á 11 ára tímabili reyndist 1861 sýni af 11.968 (16\%) jákvætt fyrir C. difficile og einstakar sýkingar voru 1492. Nýgengi sýkingar var 29\% hærra í lok en upphafi tímabilsins og var að meðaltali hæst í aldurshópnum >80 ára par sem pað var 387 tilfelli á hverja 100.000 íbúa Íslands á ári. Fjöldi sýkinga á 1000 innlagnir jókst um $71 \%$ og fjöldi sýkinga á 10.000 legudaga jókst um 102\%. 92\% sýkinga tengdust heilbrigðispjónustu og $47 \%$ voru spítalasýkingar. Meirihluti sjúklinga tók sýklalyf innan priggja mánaða fyrir sýkingu. Algengasta einkenni sýkingar var niðurgangur. Yfirgnæfandi meirihluti (93\%) peirra sem nægar upplýsingar fundust um náðu bata eftir eina sýklalyfjameðferð og enginn gekkst undir aðgerð. Ályktanir: Sýkingar af völdum C. difficile voru fleiri árið 2008 á Landspítala en árið 1998. Innsendum sýnum fjölgaði hins vegar stöðugt og meira en sýkingum. Fáir sýkjast án pess að hafa einn eða fleiri pekktra áhættupátta. Í flestum tilvikum dugði stök meðferð með metrónídazóli til pess að uppræta sýkingu. Meinvirkni C. difficile virðist ekki hafa aukist hér á landi.

\section{Inngangur}

Tíðni og alvarleiki ristilbólgu af völdum Clostridium difficile (C. difficile) hefur farið vaxandi á Vesturlöndum á síðustu árum með tilkomu meinvirkari stofna. ${ }^{1}$ Faröldrum slíkra stofna hefur verið lýst frá upphafi pessarar aldar î Norður-Ameríku og Evrópu. ${ }^{1-3}$ Í Evrópu hefur verið greint frá faröldrum á 113 spítölum. ${ }^{4}$ Aukna tíðni og alvarleika C. difficile sýkinga má rekja til pessara nýju stofna bakteríunnar sem framleiða meira af eiturefnum (e. toxins), eru polnari gagnvart sýklalyfjum, eða hvort tveggja. ${ }^{1}$ Samhliða pessu hefur pörf á skurðaðgerðum aukist. $^{5}$ Pannig má nefna að tíðni sýkinga í Bandaríkjunum prefaldaðist á árunum 20002005. Pessari aukningu fylgdi fjölgun dauðsfalla, sérstaklega á meðal aldraðra. ${ }^{6}$

Sýklalyfjameðferð er aðaláhættupáttur sýkingar af völdum C. difficile. Sýklalyf raska örveruflóru ristilsins og gefa pannig C. difficile tækifæri til yfirvaxtar. Klindamýcín, priðja kynslóð kefalósporína, nýrri flúórókínólónar og amoxicillín með klavúlansýru ýta mest undir sýkingar en nánast hvaða sýklalyf sem er getur stuðlað að sýkingu. ${ }^{7}$

Einkenni geta komið fram frá upphafi sýklalyfjameðferðar og allt að premur mánuðum eftir að henni er hætt. ${ }^{4}$ Dæmigerð einkenni eru vatnskenndur niðurgangur og kviðverkir. Við skoðun er líkamshiti gjarnan hækkaður og eymsli finnast yfir neðanverðum kvið. ${ }^{9}$ Fjöldi hvítra blóðkorna getur ýmist verið eðlilegur eða gríðarlega hækkaður (>50 púsund hvít blóðkorn/ $\mathrm{mm}^{3}$ ) og alvarlegri sýkingum getur fylgt hækkun á CRP. ${ }^{8-10}$ Í alvarlegustu tilfellum er hætta á blóðsýkingu sem getur próast yfir í sýklasóttarlost og kallað á gjörgæslumeðferð.,10 Meðferð C. difficile sýkingar fer eftir alvarleika og er fyrst beitt sýklalyfjameðferð, oftast metrónídazóli eða vankómýcíni. Einnig er mikilvægt að hætta gjöf annarra sýklalyfja ef pess er kostur. Sýkingar af völdum hinna nýju meinvirkari stofna virðast svara hefðbundinni meðferð verr en sýkingar af eldri stofnum og hefur tíðni bakslaga (e. relapse) aukist hjá peim sem fá meðferð með metrónídazóli. Enn hefur pó ekki verið sýnt fram á pol meinvirkari stofna gegn metrónídazóli. ${ }^{4}$

Gjöf gersveppsins Saccharomyces boulardii ( $S$. boulardii) minnkar líkur á bakslagi hjá peim sem fá endurteknar $C$. difficile sýkingar ef hann er gefinn ásamt viðeigandi sýklalyfjum. ${ }^{11}$ Ýmis meðferðarúrræði hafa verið reynd hjá peim sjúklingum sem fá endurteknar $C$. difficile sýkingar. Vankómýcín er hugsanlega besta lausnin og samsetning stórra skammta vankómýcíns og 
S. boulardii er eina samsetta meðferðin sem sýnt hefur verið fram á að dragi úr endurteknum sýkingum. ${ }^{4}$ Nýlegar rannsóknir benda til pess að í erfiðum tilvikum megi lækna og ná jafnvægi í parmaflóru sjúklinga með pví að gefa peim hægðainnihald í meltingarveg og pá helst frá maka eða nákomnum ættingja. ${ }^{12}$

Síðasta meðferðarúrræði við alvarlegri C. difficile ristilbólgu er að nema brott ristil, að fullu eða að hluta. Sjúklingar með svæsna ristilbólgu og merki um lífhimnubólgu eða rof á ristli purfa oft algjört ristilnám..$^{13}$ Lykillinn að bættri meðferð er að greina sjúkdóminn snemma og framkvæma skurðaðgerð sem fyrst. Ein rannsókn sýndi að lífslíkur sjúklinga eru töluvert betri eftir skurðaðgerð ef hún er gerð áður en peir purfa á æðaherpandi lyfjum, aðstoð öndunarvélar eða hvoru tveggja að halda. ${ }^{14}$

Faraldsfræði C. difficile sýkinga á Íslandi hefur ekki verið rannsökuð en í ljósi slæmrar próunar víða erlendis er mikilvægt að kanna hana á Landspítala, stærstu heilbrigðisstofnun landsins. Markmið rannsóknarinnar var að rannsaka faraldsfræði og alvarleika C. difficile sýkinga árin 1998-2008.

\section{Efniviður og aðferðir}

\section{Skilgreining tilfella}

Rannsóknarpýðið voru sjúklingar á Landspítala með jákvæð eiturefnapróf í hægðum samkvæmt gagnagrunni sýklafræðideildar spítalans árin 1998-2008. Jafnframt var aflað upplýsinga um heildarfjölda hægðasýna sem send voru inn til C. difficile leitar á sama tíma. Greining sýklafræðideildar á eiturefnum C. difficile var gerð með premur mismunandi prófum á tímabilinu.
Árin 1998-2000 var notað Premier C. difficile Toxin A (Meridian Diagnostics, Inc.). Frá árinu 2001 fram í febrúar 2005 var notað C. difficile Tox-A Test (Techlab, Inc.) og frá febrúar árið 2005 hefur verið notað C. difficile Tox A/B II TM (Techlab, Inc.) sem sker sig frá hinum að pví leyti að pað greinir bæði eiturefni A og B.

Ef tvö eða fleiri jákvæð sýni voru frá sama sjúklingi voru pau talin endurspegla sömu sýkingu eða bakslag hennar ef tímabil milli peirra var styttra en 28 dagar og pá var sýking talin stök. Ef 28 eða fleiri dagar skildu að jákvæð sýni var talið að um endurteknar sýkingar væri að ræða. Í sumum tilfellum voru niðurstöður eiturefnaprófs taldar falskt jákvæðar til að mynda vegna blóðs í hægðum og voru pau tilfelli útilokuð. Allar sýkingar voru pví á endanum annaðhvort flokkaðar stakar eða endurteknar eftir að falskt jákvæð próf höfðu verið útilokuð. Spítalasýkingar voru skilgreindar sem sýkingar sem greindust eftir tveggja sólarhringa dvöl eða lengri á sjúkrahúsinu. Sýkingar tengdar heilbrigðispjónustu voru skilgreindar sem sýkingar hjá einstaklingum sem legið höfðu á spítala einhvern tímann innan priggja mánaða fyrir sýkingu. Rannsóknin var framkvæmd að fenginni heimild Persónuverndar, siðanefndar Landspítala og framkvæmdastjóra lækninga spítalans.

\section{Faraldsfræði}

Athugað var hvernig fjöldi jákvæðra sýna próaðist árin 1998-2008 og hvernig sýkingar dreifðust yfir mánuði ársins, hversu margir fengu staka sýkingu, hversu margir fengu endurteknar sýkingar og kynjahlutfall. Einnig var athugað innan hvaða sviða flestar sýkingar höfðu greinst árin 1998-2008 og hvernig pær dreifðust milli

Tafla I. Tölur yfir sýkingar á Landspítala í samhengi við innlagnir og legudaga ásamt meðaltölum. Upplýsingar um innlagnir og legudaga voru fengnar úr starfsemisupplýsingum spítalans og ársskýrslum Sjúkrahúss Reykjavíkur og Ríkisspítala. ${ }^{16-19}$

\begin{tabular}{|c|c|c|c|c|c|}
\hline Ár & Sýkingar & Innlagnir & $\begin{array}{c}\text { Sýkingar á } 1000 \\
\text { innlagnir }\end{array}$ & Legudagar & $\begin{array}{c}\text { Sýkingar á } 10.000 \\
\text { legudaga }\end{array}$ \\
\hline 1998 & 92 & 33.030 & 2,8 & 342.422 & 2,7 \\
\hline 1999 & 98 & 34.897 & 2,8 & 332.718 & 2,9 \\
\hline 2000 & 96 & 35.643 & 2,7 & 321.322 & 3,0 \\
\hline 2001 & 163 & 32.709 & 5,0 & 301.874 & 5,4 \\
\hline 2002 & 179 & 32.477 & 5,5 & 298.559 & 6,0 \\
\hline 2003 & 177 & 31.687 & 5,6 & 282.258 & 6,3 \\
\hline 2004 & 157 & 31.583 & 5,0 & 260.532 & 6,0 \\
\hline 2005 & 176 & 31.060 & 5,7 & 258.764 & 6,8 \\
\hline 2006 & 85 & 27.943 & 3,0 & 255.259 & 3,3 \\
\hline 2007 & 132 & 27.241 & 4,8 & 245.155 & 5,4 \\
\hline 2008 & 137 & 28.607 & 4,8 & 232.570 & 5,9 \\
\hline $\begin{array}{c}\text { Meðaltal } \\
\text { (staðalfrávik) }\end{array}$ & $\begin{array}{l}136 \\
( \pm 37)\end{array}$ & $\begin{array}{l}31.534 \\
( \pm 2699)\end{array}$ & $\begin{array}{c}4,3 \\
( \pm 1,2)\end{array}$ & $\begin{array}{l}284.676 \\
( \pm 37.251)\end{array}$ & $\begin{array}{c}4,9 \\
( \pm 1,6)\end{array}$ \\
\hline
\end{tabular}


sjúkrahúsanna í Fossvogi, við Hringbraut og á Landakoti árin 1998-2005. Auk pessa var reiknað út nýgengi fyrir hvert ár og aldursbundið nýgengi fyrir tímabilið í heild byggt á mannfjöldatölum frá Hagstofu Íslands. Meðaltöl og staðalfrávik voru reiknuð út í Excel.

\section{Skráning klínískra upplýsinga}

Til pess að kanna einkenni nánar var afráðið аð skoða upplýsingar um úrtak sjúklinga sem greindust tvo mánuði hvert ár tímabilið 1998-2008, pað er í janúar og júní öll árin. Skráðar voru upplýsingar um aldur, kyn og einkenni sýkingar. Dagsetning sýnatöku jákvæðs sýnis var skráð en ef hún fannst ekki var skráður dagurinn sem sýnið var móttekið á sýklafræðideild Landspítala. Upplýsingar um helstu lyfjaflokka sem sjúklingur notaði reglulega og sérstaklega mánuð fyrir sýkingu voru skráðar. Einnig voru skráðar upplýsingar um sýklalyfjanotkun, tegund, skammta og meðferðartíma, allt að premur mánuðum fyrir sýkingu. Sjúkdómar sem sjúklingur hafði voru flokkaðir eftir líffærakerfum. Spítalalega allt að premur mánuðum fyrir sýkingu, í tengslum við sýkingu og lega á gjörgæslu voru skráðar. Kannað var hvort sjúklingur væri búsettur á stofnun par sem samgangur væri milli vistmanna. Ef kviðskoðun var framkvæmd á sjúklingi eftir að einkenni sýkingar hófust var lýsing á henni skráð. Aðferðir til greiningar $C$. difficile sýkingu voru skráðar. Niðurstöður blóðrannsókna voru skráðar ef pær voru framkvæmdar á meðan sjúklingur hafði einkenni. Loks var athugað hvort og hvers konar meðferð sjúklingur fékk við $C$. difficile sýkingu og hvort hann purfti á endurtekinni meðferð að halda.

\section{Tölfræði}

Notast var við einfalda lýsandi tölfræði. Nýgengi sýkingar var reiknað út frá mannfjöldatölum Hagstofu Íslands ${ }^{15}$ en tölur um innlagna- og legudagafjölda fengnar úr ársskýrslum spítalans og forvera hans. ${ }^{16-19}$

\section{Niðurstöður}

\section{Heildartak}

Alls bárust sýklafræðideild Landspítala 11.968 hægðasýni frá sjúklingum árin 1998-2008 par sem óskað var eftir leit að eiturefnum $C$. difficile. Fjöldi innsendra sýna jókst jafnt og pétt yfir tímabilið og fór úr 794 árið 1998 í 1341 árið 2008 og fjölgaði sýnum pví um 69\% á tímabilinu.

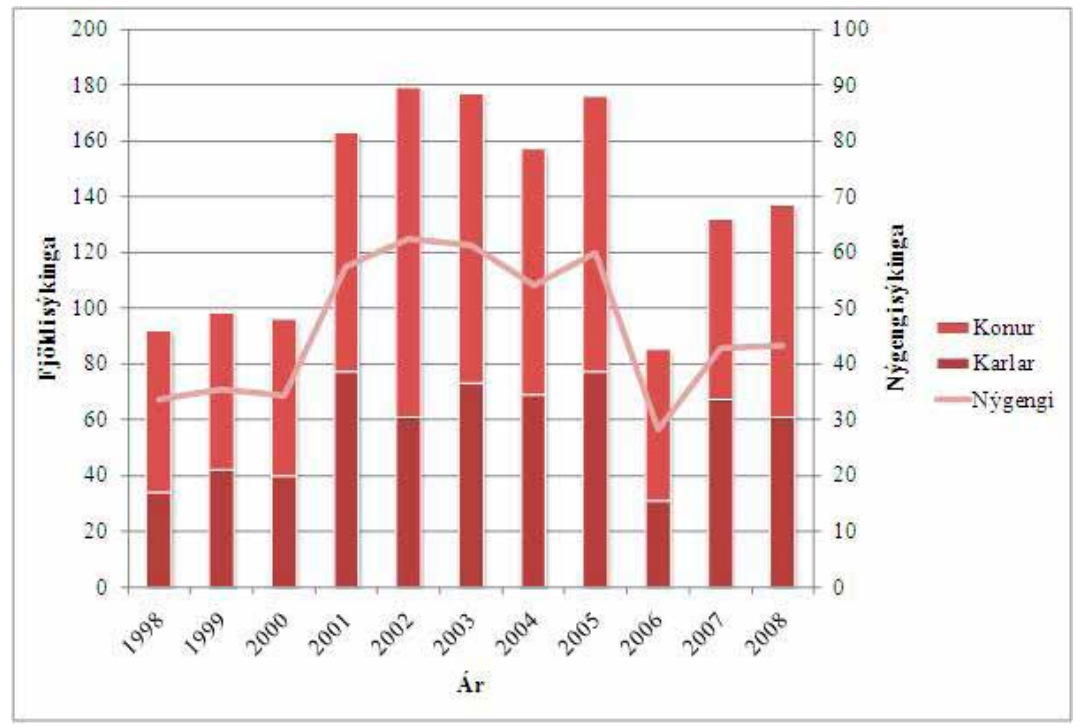

Sýni frá sjúklingum spítalans voru 63\% af heildarfjölda innsendra sýna til sýklafræðideildar en önnur sýni komu frá heilbrigðisstofnunum og -fyrirtækjum ásamt hjúkrunarheimilum á landinu. Af hægðasýnum frá sjúklingum spítalans reyndist 1861 (16\%) sýni jákvætt fyrir C. difficile. Af jákvæðum sýnum reyndust 1492 (80\%) endurspegla stakar sýkingar en 369 (20\%) voru staðfesting á áðurgreindri sýkingu og/eða pjónuðu ekki augljósum tilgangi.

Ef aðeins er miðað við jákvæð sýni frá Landspítala reiknast meðalnýgengi á fyrrgreindu 11 ára tímabili vera $47 \pm 13$ tilfelli á hverja 100.000 íbúa Íslands ár hvert. Nýgengið var nokkuð breytilegt eftir árum (bil 28,3-62,5), lægst árið 2006 en hæst árið 2002 eins og sjá má betur á mynd 1.

Sýkingarnar 1492 greindust hjá 1374 sjúklingum. Af peim fengu langflestir eða 1268 (92\%) staka sýkingu, en 106 (8\%) fengu endursýkingar og af peim fengu 94 sjúklingar tvær og 12 fengu prjár aðskildar sýkingar. Meirihluti sýkinganna greindist hjá konum eða 860 (58\%) og er skipting milli kynja sýnd á mynd 1. Aldursbundið nýgengi C. difficile sýkinga er hæst í eldra fólki og nýgengi meðal kvenna er hærra en karla eins og sjá má á mynd 2. Fjöldi sýkinga var einnig reiknaður sem hlutfall af fjölda innlagna og legudaga á Landspítala. Niðurstöðurnar má sjá í töflu I og sést par að á sama tíma og innlögnum og legudögum hefur fækkað hefur heildarfjöldi sýkinga aukist. Ef borin eru saman fyrstu tvö ár tímabilsins við tvö pau síðustu hefur fjöldi sýkinga á hverjar 1000 innlagnir aukist um 71\% og fjöldi sýkinga á hverja 10.000 legudaga hefur aukist um 102\%. Spítalasýkingar voru 112 eða 47\% af heildarfjölda sýkinganna og langflestar sýkinganna voru tengdar heilbrigðispjónustu (219/237, 92\%).
Mynd 1. Fjöldi og kynjaskipting ásamt nýgengi $C$. difficile sýkinga á Landspitala á hverja 100.000 íbúa Íslands árin 1998-2008. Íbúafjöldi var fenginn frá Hagstofu Íslands. ${ }^{15}$ 


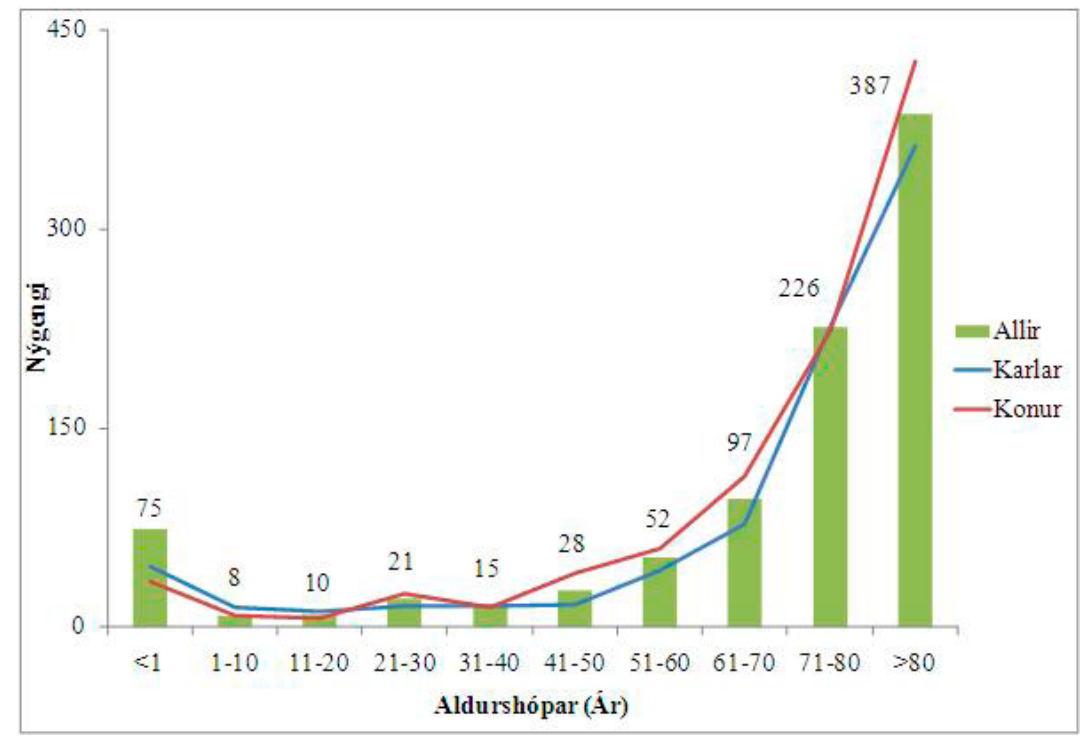

Mynd 2. Aldursbundið nýgengi C. difficile sýkinga á Landspítala á hverja 100.000 karla, konur og íbúa Íslands árin 1998-2008. Íbúafjöldi var fenginn frá Hagstofu Íslands. ${ }^{15}$

\section{Kerfisbundið úrtak}

Á mynd 3 kemur fram fjöldi tilfella eftir mánuðum auk fjölda tilfella miðað við innlagnir. Pegar rýnt er í myndina má sjá að breytileiki î fjölda tilfella milli mánaða útskýrist að einhverju leyti af umsvifum í starfsemi spítalans. Hún sýnir talsverðan breytileika milli ára en með hana til hliðsjónar var afráðið að taka kerfisbundið úrtak úr heildarpýðinu pannig að farið var yfir sjúkraskrár allra peirra sem greindust tvo mánuði, janúar og júní, innan hvers árs en pað reyndust vera alls 249 sýkingar. Af pessum hópi reyndust 12 (5\%) sýkingar vera byggðar á falskt jákvæðum eiturefnaprófum. Pví voru 237 C. difficile sýkingar rannsakaðar nákvæmlega með tilliti til áhættupátta, birtingarforms, meðferðar og afdrifa sjúklinga, með pað fyrir augum að kanna hvort einhver pessara pátta hefði breyst á tímabilinu.

Að minnsta kosti 72\% peirra sem sýktust höfðu tekið sýklalyf innan priggja mánaða fyrir greiningu sýkingar. Langflestir peirra höfðu tekið sýklalyf af penicillín-flokki (90\%) og innan pess flokks höfðu flestir tekið amoxicillín með klavúlansýru (44\%) en næst kom cloxacillín (16\%). $42 \%$ höfðu tekið lyf úr flokki annarrar og priðju kynslóðar kefalósporína og 25\% flúórókínólóna. Tæpur priðjungur (30\%) sjúklinga tók einhvers konar ónæmisbælandi lyf. Flestir (78\%) voru greindir í spítalalegu og voru 88\% sjúklinga með niðurgang. Önnur einkenni, líkt og kviðverkir, ógleði, slappleiki og uppköst, komu fram í aðeins um fjórðungi tilfella. Um $28 \%$ sjúklinga höfðu hita yfir $38,3^{\circ} \mathrm{C}$ og var hæsti hiti $41,1^{\circ} \mathrm{C}$ en $40 \%$ allra sjúklinga höfðu hækkuð hvít blóðkorn.
Upplýsingar um meðferð við C. difficile sýkingu fundust í sjúkraskrám fyrir 187 (79\%) sjúklinga af peim 237 sýkingum sem voru rannsakaðar. Langflestar (173/187, 93\%) peirra sem unnt var að leggja mat á voru upprættar með sýklalyfjameðferð. Í $84 \%$ peirra tilfella var veitt meðferð með metrónídazóli, 5\% með vankómýcíni og 10\% með báðum lyfjum. Einn fékk meðferð með vankómýcíni og rífampícíni og einn fékk ónafngreint sýklalyf. $25(13 \%)$ fengu viðbótarmeðferð með lifandi bakteríum (Lactobacillus acidophilus, Lactobacillus bifidus) og allir nema einn peirra fengu hana ásamt sýklalyfjum. 23 (13\%) peirra sem fengu meðferð með lyfjum purftu á endurtekinni sýklalyfjameðferð að halda vegna bakslaga. Par af fengu 13 fullan bata eftir tvær sýklalyfjameðferðir, fimm peirra eftir prjár en fimm purftu á fjórum sýklalyfjameðferðum að halda til pess að ná fullum bata. Enginn peirra, sem rannsakaðir voru, purfti að gangast undir aðgerð vegna $C$. difficile sýkingar og enginn lést af völdum hennar. Af peim sjúklingum, sem voru í úrtaki, létust 21/237 í sömu legu eða 9\%. Sýkingin var ekki talin aðaldánarorsök í neinu tilviki.

\section{Umræða}

Innsendum hægðasýnum til leitar að eiturefnum C. difficile fjölgaði árin 1998-2008. Nýgengi C. difficile sýkinga á Landspítala hækkaði frá árinu 1998 til ársins 2008 hvort sem miðað er við íbúafjölda Íslands, innlagnir eða legudaga. Mesta athygli vekur toppur í nýgengi árin 20012005 og svo lægðin sem fylgir á eftir árið 2006. раð veikir rannsóknina og skekkir niðurstöður hennar að notuð voru prjú ólík greiningarpróf á tímabilinu sem var rannsakað. Sveiflur í nýgengi sýkinga verða um svipað leyti og skipt er um greiningarpróf. Greiningarpróf fyrir C. difficile sem notuð voru fram að janúar árið 2005 gáfu falskt jákvætt svar ef blóð var í hægðum sjúklinga. Prófið sem tekið var í notkun pá gerir pað hins vegar ekki. Á móti pessu kemur að nýja prófið greinir toxín A og B en pað gamla greindi aðeins toxín A. Nýja prófið greinir pví fleiri réttilega jákvæða en engan falskt jákvætt vegna blóðs í sýni. Pví er ekki augljóst hvernig greiningarprófin skekkja niðurstöðurnar. Toppurinn nær hins vegar út árið 2005 svo nýtt greiningarpróf er ekki nægjanleg útskýring á peim sviptingum sem verða á mótum áranna 2005 og 2006. Einnig má benda á að fjöldi sýkinga er ekki mikill og geta lítil frávik breytt honum mikið og breytileiki milli ára getur verið töluverður án pess að ákveðin skýring liggi að baki. Hugsanlegt er að pættir líkt og 
tímabundin aukin árvekni heilbrigðisstarfsfólks eða faraldrar innan stakra deilda myndi hluta toppsins. Frekari rannsókna er pörf ef útskýra á breytilegt nýgengi til fulls.

Aukning í innsendum sýnum undanfarin 11 ár vekur einnig athygli. Hún stafar mögulega af aukinni árvekni heilbrigðisstarfsfólks gagnvart C. difficile sýkingum vegna fregna af aukinni tíðni og alvarleika sjúkdómsins í löndunum í kringum Ísland.

Ekki kemur á óvart að nýgengi er hæst í fólki yfir áttræðu. Með vaxandi aldri aukast líkur á ýmsum öðrum sjúkdómum, spítalalegu, dvöl á stofnunum og lyfjagjöf sem auka sýkingarhættu.

Alls voru 369 jákvæðu sýnanna árin 1998-2008 flokkuð sem ópörf aukasýni. Ýmsar ástæður liggja að baki pví að pessi sýni eru tekin. Stundum eru tekin prjú hægðasýni í röð og pau send á sama tíma til sýklafræðideildar. Рað er gert til pess að minnka líkur á að missa af sýkingu vegna falsks neikvæðs eiturefnaprófs. Til pess að draga úr kostnaði sem pessu fylgir væri skynsamlegra að senda eitt sýni í einu par sem ekki er pörf á fleiri sýnum eftir að eitt hefur reynst jákvætt. Einnig er nokkuð um að hægðasýni séu send til sýklafræðideildar til pess að athuga árangur meðferðar við C. difficile sýkingu. Niðurstöður eiturefnaprófa á slíkum sýnum eru ekki gagnlegar. Рær geta verið afvegaleiðandi par sem priðjungur peirra, sem hafa náð fullum bata með sýklalyfjum, skilur eiturefni $C$. difficile út í hægðum í einhvern tíma eftir meðferð..$^{20}$ Aukin fræðsla til lækna um rétta notkun prófsins er pví við hæfi.

Rannsókn á sýkingum í janúar og júní var afturskyggn og var erfitt að finna pau gögn sem ætlunin var að safna. Flestir höfðu tekið sýklalyf fyrir C. difficile sýkingu. Notkun penicillína, kefalósporína og flúórókínólóna var áberandi hjá pessum einstaklingum en pað er svipað pví sem pekkt er annars staðar í heiminum. ${ }^{7}$ Ekki kemur heldur á óvart að flestir voru greindir í spítalalegu en rétt tæplega helmingur sýkinganna (47\%) voru spítalasýkingar eða 112/237. Einnig vekur sérstaka athygli hversu mikil aukning er á tíðni sýkinganna ef miðað er við legudagafjölda á sjúkrahúsinu. Pær niðurstöður endurspegla pá próun sem átt hefur sér stað á undanförnum árum í rekstri sjúkrahúsa á Vesturlöndum, að legudögum fækkar, en sjúklingar eru veikari meðan á dvöl peirra stendur og hætta á spítalasýkingum pví meiri. Nýlegar rannsóknir benda til pess að aukakostnaður vegna frumsýkingar með C. difficile sé 5.243 - 8.570 Bandaríkjadalir en 13.655 dalir fyrir pá sem fengu bakslög. ${ }^{21}$ Pví er ljóst að til mikils er að vinna við að halda tíðninni í lágmarki.

Vert er að veita pví athygli að langalgengasta

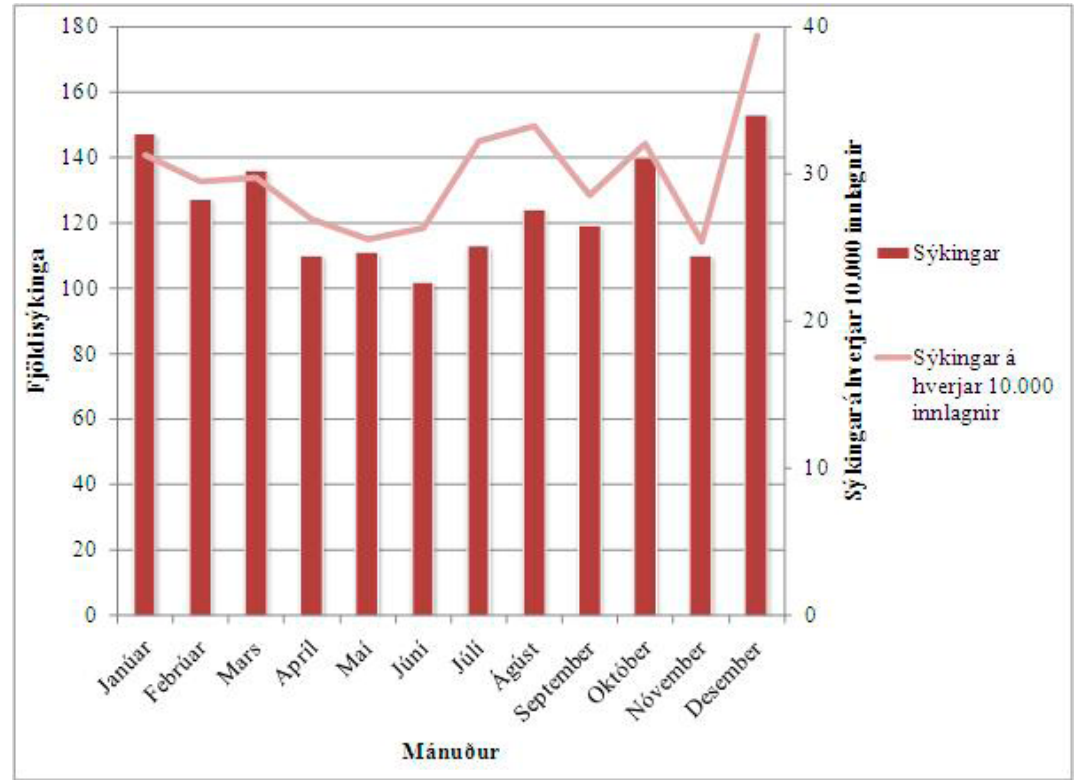

einkenni sýkingar er niðurgangur og í sumum tilfellum er hann eina einkenni sýkingar. Pó er líklegt að vanskráning annarra einkenna geri minna úr hlut peirra en hann í raun og veru er. Pá ber einnig að hafa í huga hversu lágt hlutfall sjúklinga hefur hita og hækkuð hvít blóðkorn prátt fyrir sýkingu. Hins vegar er líkamshiti ekki alltaf færður samviskusamlega inn í sjúkraskrá og í nokkrum tilfellum voru upplýsingar um blóðrannsóknir ekki til staðar.

Niðurstöður okkar sýna að metrónídazól er fyrsti meðferðarkostur við C. difficile sýkingum á Íslandi og virðist duga til lækningar í flestum tilvikum. Fjöldi peirra sem fengu aðra meðferð en metrónídazól var ekki nægilega mikill til pess að hægt væri að bera saman við árangur annarrar meðferðar. Metrónídazól er víðast hvar talið kjörlyf við vægari C. difficile sýkingum auk pess að samkvæmt leiðbeinandi lyfjaverði Lyfjastofnunar Íslands er meðferð með metrónídazóli meira en fimmfalt ódýrari en meðferð með vankómýcíni. ${ }^{22,23}$

Markmið rannsóknarinnar var að skýra frá próun C. difficile sýkinga árin 1998-2008 á Landspítala og athuga hvort alvarlegri sýkingar hafi greinst hér á síðari árum. Ekki voru tekin með sýni sem send voru sýklafræðideild frá öðrum stöðum. Gagnagrunnur sýklafræðideildar reyndist innihalda mun áreiðanlegri upplýsingar um umfang pessara sýkinga en útskriftargreiningar, pví $C$. difficile sýking var aðeins skráð í útskriftargreiningu 37 (20\%) peirra einstaklinga í okkar úrtaki sem greindir voru með sýkinguna í spítalalegu. Sýkingin er pví mjög vantalin í sjúklingabókhaldi spítalans. Með pví að fara eftir gagnagrunni sýklafræðideildar er unnt að missa af tilfellum sem einungis eru greind
Mynd 3. Fjöldi C. difficile sýkinga á Landspítala eftir mánuðum og á hverjar 10.000 innlagnir í tilteknum mánuði árin 1998-2008. 
út frá einkennum, holspeglun, myndgreiningu eða öðrum aðferðum. Fjöldi slíkra tilfella er pó hverfandi pví pótt aðrar aðferðir geti vakið grun um sýkingu er sá grunur yfirleitt staðfestur með eiturefnaprófi í hægðasýni.

Vegna hins mikla fjölda sýkinga var of viðamikið að fara yfir sjúkragögn allra sem greindust með C. difficile niðurgang árin 19982008 og takmarkar pað rannsóknina nokkuð. Á hinn bóginn gefur pessi rannsókn sterkar vísbendingar um að alvarleiki pessara sýkinga hafi ekki aukist hér á landi, gagnstætt pví sem gerst hefur í nágrannalöndum okkar. Mánuðirnir janúar og júní voru valdir par sem langt er á milli mánaðanna, annar endurspeglar sýkingar að sumarlagi og hinn að vetrarlagi. Fæstar sýkingar voru greindar í júní en næstflestar í janúar. Með pessu vali er pví talið að pversnið hafi fengist af heildarpýðinu. Раð má hins vegar velta pví upp hvort betra hefði verið að slembivelja úrtakið.

Eins og áđur segir eru tíðnitölur fyrir sjúkdóminn ekki til á Íslandi. Niðurstöður pessarar rannsóknar veita pví nýjar og ágætar upplýsingar um próun $C$. difficile sýkinga á Landspítala og vísbendingu um stöðuna á landsvísu. Enda pótt nýgengi sýkinga hafi aukist er ljóst að við búum enn við mun lægri sýkingatíðni en til að mynda í Bandaríkjunum og Kanada par sem nýgengið hefur margfaldast síðastliðinn áratug vegna tilkomu meinvirkari stofna. ${ }^{24,25}$

Enginn sjúklingur í okkar rannsókn purfti að gangast undir aðgerð vegna C. difficile sýkingar og langflestir náðu bata eftir staka sýklalyfjameðferð með metrónídazóli. Í peim tilfellum er sjúklingar létust í sömu legu og C. difficile sýking greindist var sýkingin ekki aðaldánarorsökin. Pessar niðurstöður benda pví ekki til pess að meinvirkari stofnar $C$. difficile hafi náð útbreiðslu á Íslandi enn sem komið er en hætta er á að peir berist hingað á næstu árum. Nauðsynlegt er að hafa eftirlit með faraldsfræði pessa sjúkdóms innan veggja spítalans og æskilegt að aðstaða sé fyrir hendi til pess að stofngreina bakteríur sem valda alvarlegum sýkingum. Hvort tveggja er forsenda pess að unnt sé að bregðast tímanlega við er meinvirkari stofnar hefja innreið sína hér á landi.

\section{Pakkir}

Gunnhildur Jóhannsdóttir, skrifstofustjóri á skurðlækningasviði Landspítala, fær pakkir fyrir ýmsa hjálp pann tíma sem á rannsókninni stóð. Starfsfólki sýklafræðideildar eru færðar pakkir fyrir hjálp við öflun gagna fyrir rannsóknina. Einnig fær starfsfólk skjalasafns Landspítala í Vesturhlíð pakkir fyrir hjálp við öflun sjúkraskráa.

\section{Heimildir}

1. Kuijper EJ, Coignard B, Tüll P. Emergence of Clostridium Difficile-Associated Disease in North America and Europe. Clin Microbiol Infect 2006; 12 Suppl 6: 2-18.

2. Goorhuis A, Bakker D, Corver J, et al. Emergence of Clostridium Difficile Infection due to a New Hypervirulent Strain, Polymerase Chain Reaction Ribotype 078. Clin Infect Dis 2008; 47: 1162-70.

3. Warny M, Pepin J, Fang A, et al. Toxin Production by an Emerging Strain of Clostridium Difficile Associated with Outbreaks of Severe Disease in North America and Europe. Lancet 2005; 366: 1079-84

4. Hookman P, Barkin JS. Clostridium Difficile Associated Infection, Diarrhea and Colitis. World J Gastroenterol 2009; 15: 1554-80.

5. Miller MA. Clinical Management of Clostridium DifficileAssociated Disease. Clin Infect Dis 2007; 45 Suppl 2: S122-8.

6. Gerding DN, Muto CA, Owens RC Jr. Measures to Control and Prevent Clostridium Difficile Infection. Clin Infect Dis 2008; 46 Suppl 1: S43-9.

7. Owens RC Jr, Donskey CJ, Gaynes RP, Loo VG, Muto CA. Antimicrobial-Associated Risk Factors for Clostridium Difficile Infection. Clin Infect Dis 2008; 46 Suppl 1: S19-31.

8. Hardt C, Berns T, Treder W, Dumoulin FL. Univariate and Multivariate Analysis of Risk Factors for Severe Clostridium Difficile-Associated Diarrhoea: Importance of Co-Morbidity and Serum C-Reactive Protein. World J Gastroenterol 2008; 14: 4338-41.

9. Bartlett JG, Gerding DN. Clinical Recognition and Diagnosis of Clostridium Difficile Infection. Clin Infect Dis 2008; 46 Suppl 1: S12-8.

10. Bartlett JG. Historical Perspectives on Studies of Clostridium Difficile and C. Difficile Infection. Clin Infect Dis 2008; 46 Suppl 1: S4-11.

11. McFarland LV, Surawicz CM, Greenberg RN, et al. A Randomized Placebo-Controlled Trial of Saccharomyces Boulardii in Combination with Standard Antibiotics for Clostridium Difficile Disease. JAMA 1994; 271: 1913-8.

12. Aas J, Gessert CE, Bakken JS. Recurrent Clostridium difficile Colitis: Case Series Involving 18 Patients Treated with Donor Stools Administered via a Nasogastric Tube. Clin Infect Dis 2003; 36: 580-5

13. Koss K, Clark MA, Sanders DS, Morton D, Keighley MR, Goh J. The Outcome of Surgery in Fulminant Clostridium Difficile Colitis. Colorectal Dis 2006; 8: 149-54.

14. Hall JF, Berger D. Outcome of Colectomy for Clostridium Difficile Colitis: A Plea for Early Surgical Management. Am J Surg 2008; 196: 384-8.

15. www.hagstofan.is - Mannfjöldatölur

16. www.landspitali.is - Starfsemisupplýsingar 2006

17. www.landspitali.is - Starfsemisupplýsingar 2008

18. www.landspitali.is - Ársskýrslur Ríkisspítala 1999

19. www.landspitali.is - Ársskýrslur Sjúkrahúss Reykjavíkur 1999

20. Bartlett JG. Clinical Practice. Antibiotic-Associated Diarrhea. N Engl J Med 2002; 346: 334-9.

21. Ghantoji SS, Sail K, Lairson DR, Dupont HL, Garey KW. Economic Healthcare Cost of Clostridium Difficile Infection: A Systematic Review. J Hosp Infect 2009; rafræn útgáfa fyrir prentun.

22. Gerding DN, Muto CA, Owens RC Jr Treatment of Clostridium difficile Infection. Clin Infect Dis 2008; 46 Suppl 1: S32-42.

23. www.lyfjastofnun.is - Lyfjaupplýsingar

24. Pepin J, Valiquette L, Alary ME, et al. Clostridium DifficileAssociated Diarrhea in a Region of Quebec from 1991 to 2003: A Changing Pattern of Disease Severity. CMAJ 2004; 171: 46672.

25. Zilberberg MD, Shorr AF, Kollef MH. Increase in Adult Clostridium Difficile-Related Hospitalizations and CaseFatality Rate, United States, 2000-2005. Emerg Infect Dis 2008; 14: 929-31. 


\section{Clostridium difficile infections at Landspítali - 1998-2008}

Objective: To study the epidemiology and severity of $C$. difficile infections (CDI) at Landspítali over 11 year period, 1998-2008.

Material and methods: CDI were identified by a positive toxin assay in stools from the database of the Department of Microbiology. Chart review was conducted on patients diagnosed in January and June each year during the study period, a total of 237 infections.

Results: Overall, 1,861 of 11,968 submitted stool samples were positive for $C$. difficile toxin, representing 1,492 infections. The population-based incidence was $29 \%$ higher in the end than in the beginning of the period and was highest in the age group $>80$ years where it was 387 cases per 100,000 person-years. The incidence per
1,000 admissions and 10,000 hospital days increased by $71 \%$ and $102 \%$, respectively. $47 \%$ of the infections were nosocomial. Most patients had history of antibiotic exposure prior to the infection and the most common symptom was diarrhea. Response to a single antibiotics course was good (93\%). No patient required surgery due to colitis.

Conclusion: The incidence of CDI was higher in 2008 than 11 years before. Most patients had well characterized risk factors for $\mathrm{CDI}$. For most patients a single course of metronidazole treatment resolved the infection. Based on these data, the severity of CDI does not seem to be increasing in Iceland.

Kvaran RB, ValsdottirEB, Sigurdsson HK, Gottfredsson M.

Clostridium difficile infections in Landspítali 1998-2008 /cel Med J 2010; 96: 523-9

Key words: Clostridium difficile, antibiotics, colitis, epidemiology, nosocomial infections.

Correspondence: Elsa Björk Valsdóttir elsava@landspitali.is

Barst: 29. mars 2010, - sampykkt til birtingar: 9. ágúst 2010 Hagsmunatengsl: Engin 